\title{
The Reference in Case C-396/11 Radu: When does the Protection of Fundamental Rights Require Non-execution of a European Arrest Warrant?
}

\author{
Alex Tinsley ${ }^{\star}$
}

\section{Introduction}

A person facing with extradition to another country may raise concerns about the manner he will be treated in the requesting state. He may allege that, because of known deficiencies in the other state's criminal justice system, he will be inadequately protected against unsafe conviction.

The system of 'surrender' between EU Member States established by the European Arrest Warrant (EAW) Framework Decision ${ }^{1}$ is based on the idea that all the countries involved respect the same fundamental standards of fairness, in particular those required by the European Convention on Human Rights (ECHR), and that the person can therefore safely be extradited. ${ }^{2}$ Broadly, the courts of the Member States have accepted this premise and have been willing to place high levels of confidence in each other's systems. Fair Trials International's experience of individual cases, detailed in a previous issue, ${ }^{3}$ shows that this trust is not always wellfounded.

A Romanian court has recently asked the Court of Justice of the EU (CJEU) whether a judicial authority can refuse to extradite a person under an EAW where the requirements of the Charter of Fundamental Rights of the European Union are not satisfied. ${ }^{4}$ There is only limited information available about the factual background to establish the source of this question, but we know that the requested person argued before the national court that the Charter implied an obligation to assess the issuing Member State's compliance with fundamental rights and refuse execution of the EAW if it found a violation. ${ }^{5}$ Several Member States, intervening in the proceedings, also approach the question on the basis that it relates to Charter violations in the issuing Member State.

If this is in fact what is being asked, it is an important question. To answer it, the CJEU will have to state whether a Member State can be required to scrutinise the fundamental rights compliance of its fellow Member States. If that obligation can arise, the CJEU will also have to say what threshold of human rights violation needs to be reached before execution can be refused: how much evidence needs putting

\footnotetext{
* Strategic Caseworker at Fair Trials International, a human rights charity which assists people arrested outside their own country and campaigns for fair trials according to international standards.

${ }^{1}$ Council Framework Decision 2005/584/JHA of 13 June 2002 on the European Arrest Warrant and the surrender procedures between Member States OJ 2002 L 190/1.

${ }^{2}$ Rijken, 'Rebalancing security and justice', Common Market Law Review Vol. 47 (2010) p. 1473.

${ }^{3}$ Mansell, D, 'The European Arrest Warrant and Defence Rights', European Criminal Law Review Vol 2 No 1 (March 2012) pp. 36-46.

${ }^{4}$ Case C-396/11: Reference for a preliminary ruling from the Curtea de Apel Constan\#a (Romania) lodged on 27 July 2011 - Criminal proceedings against Ciprian Vasile Radu OJ 2011 C 282/15.

${ }^{5}$ Rapport d'Audience, Case C-396/11 Radu, courtesy of the Registry of the Court of Justice.
} 
forward, who by, and what sort of breach needs to be shown. Given that, standards of human rights protection within the EU are currently variable, clear answers to these questions would be very valuable.

\section{Background}

The EAW Framework Decision includes the standard recital in its preamble stating that it respects fundamental rights as enshrined in the Charter and Article 6 of the Treaty on European Union. At Article 1(3), it also provides that it 'shall not have the effect of modifying the obligation to respect fundamental rights and fundamental legal principles as enshrined in Article 6 of the Treaty on European Union'. As the Commission's first evaluation of the instrument ${ }^{6}$ revealed, two thirds of the Member States interpreted this as a power to include human rights based refusal grounds in their implementing legislation. The Commission stated its expectation that, within the EU, use of these human rights bars should be 'exceptional'. ${ }^{7}$ This has certainly proved to be the case.

\section{No common understanding of Article 1(3)}

In 2010-2011 the law firm Allen \& Overy looked at the implementing laws of eight countries for a study by Fair Trials International. We asked them to tell us about the human rights protections available in law, and about the way the courts had interpreted them. We provide a snapshot below. Broadly, the research reveals three main categories: those with no human rights protections, the French model and the more common model of generalised human rights protections which, though available in theory, are unattainable in practice.

\section{a) No human rights protection}

The Czech Republic, Hungary and Spain had no express human rights protections available in their implementing laws. Of course, requested persons can rely on constitutional protections but, at least in the Czech Republic, they will not have success. The Constitutional Court, in reviewing the implementing law against the Czech bar on extradition of Czech nationals, found that 'there is no reason to assume that the current standard of protection for fundamental rights within the EU ... offers a level of protection inferior to that which is provided in the Czech republic' 8 This is the expression of the idea of mutual recognition: systems may differ, but the shared respect for human rights means they can be trusted to afford equivalent levels of human rights protection.

\footnotetext{
${ }^{6}$ Report from the Commission based on Article 34 of the Council Framework Decision of 13 June 2002 on the European arrest warrant and the surrender procedures between Member States COM(2006) 8 final.

${ }^{7}$ Ibid, p. 5.

${ }^{8}$ Decision of the Czech Constitutional Court No. Pl. US 66/04 of 3 May 2006 (the translation used is that of the Asser Institute, Centre for International and European Law).
} 


\section{b) The French model}

The French implementing law reproduces the grounds for refusal explicitly set out in the EAW Framework Decision (though not quite adequately ${ }^{9}$ ) and, in addition, includes a ground for refusal where it is 'established' that the person is being prosecuted for discriminatory reasons, ${ }^{10}$ reflecting recital 12 in the preamble to the EAW Framework Decision. The Cour de cassation has refused to entertain arguments for refusal of EAWs falling outside the scope of these grounds: it has rejected several appeals alleging that the underlying prosecutions were founded on evidence obtained by coercion, ${ }^{11}$ and has overturned a lower court decision refusing extradition where the requested person stood to be administratively detained for 14 days without being brought before a judge. ${ }^{12}$ Each time, it has insisted that the refusal grounds contained in the implementing law are exhaustive, thus showing a steady confidence in the other Member States' ability to protect fundamental rights.

\section{c) Generalised express human rights refusal grounds}

Several countries enacted express human rights refusal grounds which appear to set different thresholds. Belgium's law requires 'serious grounds to believe' execution would infringe fundamental rights. ${ }^{13}$ The Netherlands law provides that execution can be refused where there is a 'substantiated reason to believe' that execution would lead to a 'flagrant' breach of human rights. ${ }^{14}$ The provision is interpreted in line with the case law of the European Court of Human Rights (ECtHR). ${ }^{15}$ The same reference to the ECHR is contained in the Irish and British implementing laws. ${ }^{16}$ Thus, in these countries, the case-law draws heavily on the case-law of the ECtHR, which recognises that Article 3 ECHR may require a country to refrain from extraditing or expelling a person where there are substantial grounds for believing that they will be subjected to inhuman or degrading treatment, and the right to a fair trial may also be invoked to prevent extradition where there is a risk of a 'flagrant denial of justice'. 17

As regards Article 3 ECHR, the courts in the UK and Ireland accept that execution of an EAW could be refused because of the prison conditions that await the requested person. The High Court starts from a presumption that, because the issuing Member State is a signatory to the ECHR, it can be assumed to protect fundamental rights. Around 2008, so strong was this assumption that a requested

\footnotetext{
${ }^{9}$ See Case C-42/11 Lopes Da Silva Jorge [2012] ECR I-0000.

${ }^{10}$ Article 695-22(5) of the Code de Procédure Pénale.

${ }^{11}$ Cass. crim. 15 mars 2006, RG No. 06-80927; Cass. Crim 15 avril 2008, RG No 08-82031; Cass. Crim. 5 avril 2006, RG No 06-81835. The cases all concerned alleged authors of ETA attacks and the appellants alleged evidence underlying the EAWS issued against them had been collected through coercion.

12 Cass. crim. 8 août 2007 RG No 07-84621.

${ }^{13}$ Article $4.5^{\circ}$ of the Loi du 19 décembre 2003 relative au mandat d'arrêt européen.

${ }^{14}$ Article 11 of the Overleveringswet of 29 April 2004.

${ }^{15}$ Permanent Observatory of Portuguese Justice, The European Arrest Warrant in Law and in Practice: a comparative study for the consolidation of the European law-enforcement area, Nov. 2010., p. 257.

${ }^{16}$ Section 37(1) of the European Arrest Warrant Act 2003.

${ }^{17}$ Soering v. United Kingdom App. No. 14038/88 (Judgment of 7 July 1989).
} 
person would have to show that a constitutional upheaval such as a 'military coup' was ongoing in the issuing state; evidence tending to the contrary did not, in principle, even need to be considered. ${ }^{18}$ However, following developments in asylum law (discussed below), the High Court revised the test and the current position is that a requested person would need to put forward 'clear and cogent evidence' of a generalised problem in the issuing Member States' prisons in order to reverse that presumption. ${ }^{19}$ Under Article $6 \mathrm{ECHR}$, the courts apply the 'flagrant denial of justice' test and, again, place great reliance on the status of the issuing Member State as a Contracting State of the ECHR, which 'should be readily assumed capable of protecting against an unfair trial'. ${ }^{20}$ However, Membership of the Council of Europe is not a complete answer 'where there are reliable reports that the authorities have resorted to, or tolerated, practices contrary to the principles of the [ECHR]'. ${ }^{21}$

The above snapshot of national law and practice shows that there is no common understanding, first, of whether there is a human rights exception to the rule of mutual recognition. In those Member States whose laws include human rights bars, there seems to be a common reliance on the idea of 'flagrancy', which in practice is a very high hurdle to meet. There is not, however, any clear single standard being applied, which means the EAW is currently operating in a limbo of variable geometry. With no immediate prospect of reform to clarify matters, it falls to the CJEU to provide uniformity.

\section{The Fourth Question in Radu}

The fourth question of the Curtea de Apel Constanta in Radu asks whether a Member State can, without failing its obligations under the EAW Framework Decision, refuse to execute an EAW on the grounds that the requirements of Article 6 of the Charter, which protects the right to liberty, are not satisfied. Several Member States have intervened to propose answers.

According to the Government of Romania, the mechanisms provided for by the EAW Framework Decision would be deprived of their effects if the executing state were able to refuse execution based on grounds not listed in it; to allow the issuing Member State to look beyond those grounds would impinge upon the idea of mutual trust. According to the German Government, the executing judicial authority can refuse execution if there is a 'manifest' violation of 'European fundamental rights' by the issuing state. According to the Lithuanian Government, 'on an exceptional basis', where execution would infringe fundamental human rights, the executing Member State is entitled, and is in fact obliged, to refuse execution. According to the Austrian Government, a Member State's judicial authorities can

\footnotetext{
${ }^{18}$ R (Rot) v District Court of Lublin, Poland [2010] EWHC 1820 (Admin).

19 Agius v Court of Magistrates Malta [2011] EWHC 759 (Admin), at [18].

${ }^{20}$ Janovic v Prosecutor General's Office, Lithuania [2011] EWHC 710 (Admin), at [25].

21 Ibid.
} 
refuse execution of an EAW where there are 'serious reasons to believe' that execution would infringe the requested person's fundamental rights as protected by the Union legal order. According to the Polish Government, the executing authority can, without breaching its obligations under the Treaty, refuse execution on the ground that this would entail a breach of fundamental rights, provided that this is consistent with the objectives of the EAW Framework Decision and this facility be used only 'on an exceptional basis'. According to the United Kingdom, the judicial authority could, in principle, refuse to execute an EAW where the 'exceptional circumstances' of the case entitle it to find that the person would, if surrendered to the judicial authorities of the issuing Member State, be subjected to a 'flagrant' violation of their fundamental rights. ${ }^{22}$

Thus, we see in the Member States' responses the same insistence on the idea of exceptionality, and the same lack of agreement as to what the appropriate test is. There are three questions that need resolving. First, can the Charter require a Member State to scrutinise the situation in the issuing Member State? Secondly, what sort of violation would have to be shown in order to entitle a Member State to refuse to execute an EAW? Thirdly, are there implied rules as to the evidential standard and burden of proof? We will address each of these questions below.

\section{Can the Charter require scrutiny of another Member State's respect for fundamental rights?}

The answer to this question depends on the applicability of the Charter to the decision to execute an EAW, which is the subject of a separate question in the reference. It is submitted that the point should now be considered uncontroversial: the Charter is addressed to Member States when they implement EU law, ${ }^{23}$ which means when they act within the scope of EU law, ${ }^{24}$ and they clearly do so when they arrest and extradite someone further to the system established by the EAW Framework Decision.

The key question, therefore, is whether the Member State is then required to scrutinise the criminal justice system of the issuing state. The case-law of the CJEU and ECtHR in the area of the Common European Asylum System may shed some light on the answer.

\section{a) Dublin transfers}

Similarly to the EAW system, the system of transfer of asylum-seekers between Member States established by the 'Dublin II' Regulation' ${ }^{25}$ rests on an assumption

\footnotetext{
${ }^{22}$ All of these responses are contained in the Rapport d'audience, supra note 3 . The wording is translated from the original French.

${ }_{23}$ Article 51(1) of the Charter.

${ }^{24}$ See the Explanations to the Charter of Fundamental Rights of the European Union, OJ 2007 C 303/17.

${ }^{25}$ Council Regulation (EC) No 343/2003 of 18 February 2003 establishing the criteria and mechanisms for determining the Member State responsible for examining an asylum application lodged in one of the Member States by a third-country national OJ 2003 L $50 / 1$.
} 
that all will abide by their international obligations and safeguard the rights of those transferred to their territory. Through a series of important judgments, the ECtHR and CJEU have together confirmed that this assumption is not absolute and can be rebutted by evidence.

When the Greek asylum system began to break down under the weight of unprecedented numbers of refugees from 2006 onwards, transfers back to Greece were resisted on the grounds that the asylum-seeker risked being received in poor conditions, and, because of the ineffectiveness of the asylum system, being sent back to dangerous countries in breach of international law.

It had been established in the context of the previous incarnation of the Dublin system that, under the ECHR, a state transferring an asylum-seeker to another Contracting State to have his claim determined there, could not be absolved of the responsibility of ensuring that he would not, as a result of the decision to expel, be exposed to treatment contrary to Article 3 ECHR. ${ }^{26}$

In K.R.S. ${ }^{27}$ the ECtHR reiterated that principle applied equally in the Dublin II context but found that 'in the absence of proof to the contrary' there was a 'presumption' that Greece would comply with its obligations under the directives to prevent unlawful refoulement. ${ }^{28}$ Failing that, it was also to be presumed that Greece would comply with its obligation to ensure access to the ECtHR's own mechanisms. In respect of the physical conditions awaiting the transferred asylum-seekers, the ECtHR expressed 'concern' at the grim picture obtaining in Greece, but found that any claim arising in that regard should be pursued first with Greek and failing that to the ECtHR.

The decision was remarkable in that the ECtHR effectively accepted a central role in guaranteeing Convention rights, which sat awkwardly with its established function as a subsidiary protection mechanism. ${ }^{29}$ It also effectively required asylumseekers to suffer ill-treatment and claim a remedy ex post, which Fair Trials International has argued elsewhere is wrong in principle. ${ }^{30}$

This was, evidently, not sustainable and in the subsequent case M.S.S. ${ }^{31}$ (in which the applicant had been transferred from Belgium to Greece and had suffered harm, including attempted refoulement to Turkey), the ECtHR found that Belgium should have considered the presumption of compliance rebutted. It found that in light of the numerous reports of reputable human rights organisations detailing the problems in Greece, Belgium should have paid more attention to these than to the existence of theoretical safeguards in Greece's legislation and the Greek government's standardised assurances. 32

\footnotetext{
26 T.I. v. United Kingdom App. No. 43844/98 (Admissibility decision of 7 March 2000), p. 15.

${ }^{27}$ K.R. S. v. United Kingdom App. No 32733 (Admissibility decision of 2 December 2008).

${ }^{28}$ See pp. $16-18$ in particular.

${ }^{29}$ See Kudla v. Poland App. No. $30210 / 96$ (26 October 2000), at [152]; R (Ramda) v Secretary of State for the Home Department [2002] EWCA, at [27].

${ }^{30}$ Heard, C. and Mansell, D., 'The European Arrest Warrant: The Role of Judges When Rights Are at Risk', New Journal of European Criminal Law Vol 2 (2011) 02, p. 133.

${ }^{31}$ M.S. S. v. Belgium and Greece App. No. 30696/09 (21 January 2011).
} 
Before M.S. S. was decided, the English Court of Appeal had already lodged questions on the subject with the CJEU. By the time it came to answering them, M.S. S. had pre-determined the outcome. However, the N.S. ${ }^{33}$ case did not simply replicate the ECtHR's approach. It found that the Charter right to freedom from inhuman or degrading treatment would require Member States to use its discretion under the Regulation when 'they cannot be unaware' of systemic deficiencies in the asylum system of the Member State responsible under the Dublin II Regulation, which amount to substantial grounds for believing that the asylum seeker would face a real risk of being subjected to inhuman or degrading treatment if transferred there.

\section{b) Applicability of the N.S. principle to execution of an EAW}

It has previously been argued in these pages that the N.S. principle applies to EAW proceedings and should be a routine examination. ${ }^{34}$ We agree. The obligation not to remove a person where there exists a risk of inhuman or degrading treatment is unqualified, and is even reflected as a separate Charter right in Article 19(2). The distinction between expulsion and extradition is immaterial. Indeed, the English courts have consistently accepted that the various 'Dublin' decisions are binding on them. ${ }^{35}$ Even the French courts, which, as we have seen, take a more restrictive view, have recognised some obligations under Article 3: considering EAWs issued by Portugal and Germany, where there was alleged to be a risk of onward refoulement to Iran and Turkey respectively, the Cour de cassation found that the executing court had to obtain assurances from the issuing states, ${ }^{36}$ thus showing a reluctance to rely absolutely on other Member States' ability to protect against Article 3 violations.

The CJEU could usefully confirm that this obligation applies equally in relation to potential violations of the rights to liberty and a fair trial and the rights of the defence, as protected by Articles 6, 47 and 48 of the Charter. The EAW Framework Decision would appear to give a special position to the prohibition of expulsion where there exists a risk of ill-treatment, reflecting it in recital 13. However, the ECtHR's case-law does not permit any such dichotomy.

First of all, Soering itself recognised that a case could exceptionally be raised under Article 6 ECHR, if there were a risk of a flagrant denial of justice. Although we will come back to this criterion, the existence of an obligation is clear. The ECtHR has also recognised that flagrant denials of the right to liberty ${ }^{37}$ could in certain

\footnotetext{
${ }^{32}$ For more detailed analysis of the judgment, see Heard and Mansell, op. cit. supra note 28, and Moreno-Lax, 'Dismantling the Dublin System: M.S. S. v. Belgium and Greece', European Journal of Migration and Law Vol 14 (2012) 1, p. 1.

${ }_{33}$ Case C-411/10 N. S. v Secretary of State for the Home Department [2011] ECR I-0000.

${ }^{34}$ Billing, F., 'The Parallel Between Non-removal of Asylum Seekers and Non-execution of a European Arrest Warrant on Human Rights Grounds: The CJEU Case of N. S. v. Secretary of State for the Home Department', Eur. Crim. Law Rev. Vol 2 (2012) 1, p. 77.

${ }^{35}$ See the cases cited supra, notes $16-18$.

${ }^{36}$ Cass. crim. 7 février 2007, RG No. 07-80162; Cass. crim. 21 novembre 2007, RG No. 07-87499.

${ }^{37}$ See Tomic v. United Kingdom App. No. 17837/03 (Admissibility decision of 14 October 2003), at [3]; Othman (Abu Qatada) v. United Kingdom App. No. 8139/09 (Judgment of 17 January 2012), at [233].
} 
circumstances imply an obligation not to expel. This approach originally concerned cases calling for a prospective assessment of possible future treatment, but it has been applied equally in retrospective cases concerning enforcement of foreign judgments. In Drozd and Janouzek, ${ }^{38}$ the ECtHR considered France's decisions to enforce a judgment of a court of Andorra (then not a member of the Council of Europe) sentencing the applicant to imprisonment. It held that Contracting States were 'obliged to refuse their co-operation if it emerges that the conviction is the result of a flagrant denial of justice'. 39

Whether this doctrine of 'indirect liability' also applies in the context of cooperation between EU Member States is answered by the T.I. and K.R. S. decisions: where the Contracting States cooperate establish international organisations, they cannot be absolved of their obligations under the Convention. There is an argument that these obligations might not subsist where the cooperation arrangement allows no discretion. But the effect of Article 1(3) of the EAW Framework Decision is to allow some discretion to refuse extradition, so the situation is not directly comparable to that obtaining under, for instance, the system for the return of abducted children under the Brussels II bis Regulation, ${ }^{40}$ where an unqualified obligation is imposed.

In principle, under Article 52(3) of the Charter, rights which correspond to ECHR rights have the same meaning and scope as the ECHR rights. So the starting point is that the above interpretation applies under the Charter. Whether the potential violation complained of relates to physical conditions, as in the asylum cases, or violations of the procedural guarantees of the rights to liberty and a fair trial, the indirect liability of the executing state can arise. However, the same provision of the Charter makes it clear that it 'shall not prevent Union law providing more extensive protection'. The important question is whether it does so in this context: in particular, does the Charter, in the EAW context, impose a 'flagrancy' requirement in the same way as the ECtHR?

\section{The standard of violation required to trigger the executing State's responsibility under the Charter}

As explained above, except under Article 3, the ECtHR case-law, as a rule, holds that a Contracting State must refuse its cooperation where there is a risk of, or there has actually been, a 'flagrant denial' of the right in question. Most of the case law relates to flagrant denials of the right to a fair trial. Hypothetical examples identified by the ECtHR include: a conviction in absentia without a right to a retrial; ${ }^{41}$ a trial which is summary in nature; ${ }^{42}$ detention without access to judicial review; ${ }^{43}$ syste-

\footnotetext{
${ }^{38}$ Drozd and Janouzek v. France and Spain App. No. 12747/87 (Judgment of 26 June 1992).

${ }^{39}$ At [110].

${ }^{40}$ Council Regulation (EC) 2201/2003 of of 27 November 2003 concerning jurisdiction and the recognition and enforcement of judgments in matrimonial matters and the matters of parental responsibility, repealing Regulation (EC) No 1347/2000 (OJ 2003 L 338/1).

${ }^{41}$ Einhorn v. France App. No. 71555/01 (Judgment of 16 October 2001), at [33].

42 Bader and Kandor v Sweden App. No. 13284/04 (Judgment of 8 November 2005), at [47].
} 
matic refusal of access to a lawyer. ${ }^{44}$ The only occasion on which the ECtHR has actually found such a violation is in the case of Abu Qatada, where it found that justice would be flagrantly denied by the use of evidence obtained by torture. ${ }^{45}$ In the same case, it confirmed unequivocally that the 'flagrancy' test applied under Article $5,{ }^{46}$ the right to liberty reflected in Article 6 of the Charter.

What is the source of the 'flagrancy test'? In Soering, the Court stated: ${ }^{47}$

„... [T] he engagement undertaken by a Contracting State is confined to "securing” ... the listed rights and freedoms to persons within its own "jurisdiction". Further, the Convention does not govern the actions of States not Parties to it, nor does it purport to be a means of requiring the Contracting States to impose Convention standards on other States. Article 1 (art. 1) cannot be read as justifying a general principle to the effect that, notwithstanding its extradition obligations, a Contracting State may not surrender an individual unless satisfied that the conditions awaiting him in the country of destination are in full accord with each of the safeguards of the Convention ...

In the instant case it is common ground that the United Kingdom has no power over the practices and arrangements of the Virginia authorities which are the subject of the applicant's complaints..."

The ECtHR thus insists on the essentially territorial reach of the ECHR. It recognises that, in principle, the behaviour of another state does not fall within the responsibility of a Contracting State. That state would, otherwise, impose its local standards upon another State. However, the ECtHR continued:

"Article 3 (art. 3) makes no provision for exceptions and no derogation from it is permissible under Article 15 (art. 15) in time of war or other national emergency. This absolute prohibition of torture and of inhuman or degrading treatment or punishment under the terms of the Convention shows that Article 3 (art. 3) enshrines one of the fundamental values of the democratic societies making up the Council of Europe ...

... It would hardly be compatible with the underlying values of the Convention, that "common heritage of political traditions, ideals, freedom and the rule of law" to which the Preamble refers, were a Contracting State knowingly to surrender a fugitive to another State where there were substantial grounds for believing that he would be in danger of being subjected to torture, however heinous the crime allegedly committed.

Thus, removal where there is a risk of treatment contrary to Article 3 is prohibited because it conflicts with the guiding principles of the ECHR. It was against that backdrop that the ECtHR considered the claim under Article 6 ECHR (Articles 47/48 of the Charter). The latter was, like Article 3 ECHR, unqualified and not capable of derogation in time of war, and occupied an important position

\footnotetext{
${ }^{43}$ Al-Moayad v. Germany App. No. 35865/03 (Admissibility decision of 20 February 2007), at [101].

${ }^{44}$ Ibid., at [102]

45 Othman (Abu Qatada), supra note 37.

${ }^{46}$ Ibid, at [233].

${ }^{47}$ All of the quotations in the next paragraphs are to be found in Soering, cited supra note 15, [86]-[90].
} 
in a democratic society. So an issue might exceptionally be raised under Article 6 ECHR if the fugitive has suffered or risks suffering a "flagrant denial of justice."

It is far from clear whether the „flagrancy“ test should apply under the Charter. To begin with, the ECtHR's adoption of that test would appear to be based on its reluctance to impose ECHR on third countries, which are not bound by it, such as the United States, the destination state in Soering. No such consideration applies under the Charter. In the EU, all Member States are bound by the same fundamental rights standards, so there is no risk of imposing those standards on another.

However, at least two admissibility decisions ${ }^{49}$ suggest that the „flagrancy“ test also applies to extraditions between Contracting States. The logic is presumably that the ECHR regulates only a country's conduct within its jurisdiction, and that the international cooperation would be impeded if one country were required to take responsibility for violations in another. Accordingly, only in the most serious cases, where the undlying value of the ECHR would be undermined, cooperation must be refused.

Again, this approach is not directly transposable to the Charter in relation to extraditions between EU Member States.Respect for human rights is the foundation of the EU in general, ${ }^{50}$ and the area of freedom, security and justice in particular. ${ }^{51}$ It is the Member State's full respect for the provisions of the ECHR that allows them to cooperate on a closer basis. It enables them to presume, in principle, that there is a 'level playing field' of respect for fundamental rights within the EU. But the corollary is the undertaking by each Member State to effectively protect the fundamental rights of those transferred. Indeed this is the coondition on which several Member States aggreed to start extraditing their own nationals.. ${ }^{52}$, There is therefore no question of EU cooperation being impeded by insistence on full respect for human rights, as this already constitutes the minimum condition for cooperation.

In that context, it makes no sense to suppose that the Member States accept those extradited may have their fundamental rights violated, but are happy to tolerate this in the name of cooperation so long as the violation is not too egregious. As Advocate-General Mengozzi has stated recently: 'there [can be no] question of the Member States contributing to the creation of an area of freedom, security and justice the effect of which would be to neglect the fundamental rights of those whose conduct may have constituted a threat to freedom, security or justice ... It is in the light of the higher principle represented by the protection of human dignity, the cornerstone of the protection of fundamental rights within the European Union legal order, that the free movement of judgments in criminal matters must not only

\footnotetext{
48 Soering, cited supra note 15, [110].

${ }^{49}$ Mann v. United Kingdom and Portugal App. No. 360/10 (Admissibility decision of 1 February 2011); Stapleton v. Ireland App. No. 56588/07 (Admissibility decision of 4 May 2010).

${ }^{50}$ Article 2 TEU

51 Article 67(1) TFEU

${ }^{52}$ See, for instance, Article 16(2) of the German Basic Law (Grundgesetz).
} 
be guaranteed but also, where appropriate, limited' ${ }^{53}$ If cooperation occurs, it must be in compliance with fundamental rights. Otherwise, it cannot happen.

This is particularly the case in light of the Roadmap on defence rights. ${ }^{54}$ This programme of 'Procedural Rights Directives' granting protections to suspects in criminal proceedings is based of Article 82(2), and serves to facilitate mutual recognition. They protect essential elements of the right to a fair trial, in order to reinforce the faith between Member States that the guarantees of Article 6 ECHR (Articles 47 and 48 of the Charter) will be respected. ${ }^{55}$ They codify the agreed minimum standard upon which cooperation can take place. It would be bizarre if a Member State could be found liable by the CJEU for having failed to meet its obligations under these directives, and yet for the Charter to permit extradition to that country under an EAW on the basis that, albeit this individual guarantee of the right to a fair trial was absent, there was not a risk of a 'flagrant denial'.

That the interpretation of the Charter should be informed by the content of the Procedural Rights Directives is perfectly reasonable. Again, a parallel with the asylum context is appropriate. The reception directive ${ }^{56}$ serves to ensure a 'dignified standard of living' to asylum seekers, and the other procedures ${ }^{57}$ and definition ${ }^{58}$ directives define the minimum standards to avoid unlawful refoulement. Thus, the CJEU was able to identify a risk of ill-treatment contrary to Article 4 of the Charter on the basis of non-compliance with the directives.

An interpretation allowing refusal of extradition where there is non-compliance, as opposed to 'flagrant' non-compliance with Charter standards in the issuing state would, in addition, act as a driver of good practice. If Member States could not secure the repatriation of wanted persons without first ensuring compliance with the Procedural Rights Directives, they could be expected to ensure their houses were in order. This would enable the EU to lead the way with regard to Council of Europe, particularly those countries contemplating accession to the EU.

Departing from the 'flagrancy' test would not affect the existing presumption that Member States comply with their obligations. That presumption would be strengthened by the entry into force of the Procedural Rights Directives so that, in practice, non-execution would remain exceptional (statistically speaking). The essential practical questions would remain the same as they are: can the presumption of compliance be dislodged, and with what evidence. But the legal standard should not be artificially and unnecessarily high. An EAW should be refused where it is established

\footnotetext{
${ }^{53}$ Opinion of Advocate-General Mengozzi in Case C-42/11 Lopes De Silva Jorge [2012] ECR I-0000, at [28].

${ }^{54}$ Resolution of the Council of 30 November 2009 on a Roadmap for strengthening procedural rights of suspected or accused persons in criminal proceedings (OJ 2009 C 295/1).

${ }^{55}$ See Morgan, C., 'Where are we now with Defence Righs?' European Human Rights Law Review 4 (2012), p. 427.

${ }^{56}$ Council Directive 2003/9/EC of 27 January 2003 laying down minimum standards for the reception of asylum seekers OJ 2003 L 31/18.

${ }^{57}$ Council Directive 2005/85/EC of 1 December 2005 on minimum standards on procedures in Member States for granting and withdrawing refugee status OJ 2005 L 326/13.

${ }^{58}$ Council Directive 2004/83/EC of 29 April 2004 on minimum standards for the qualification and status of third country nationals or stateless persons as refugees or as persons who otherwise need international protection and the content of the protection granted OJ 2004 L 304/2
} 
that there is a risk of breach, as opposed to 'flagrant' breach, of the requested person's human rights.

\section{The evidential standard and the burden of proof}

The CJEU stated in N.S. that Member States may not return an asylum-seeker the Member State responsible "where they cannot be unaware that systemic deficiencies in the asylum procedure and in the reception conditions of asylum seekers in that Member State amount to substantial grounds for believing that the asylum seeker would face a real risk of being subjected to inhuman or degrading treatment within the meaning of Article 4 of the Charter". 59

The requirement for 'substantial grounds for believing' is a constant requirement of ECtHR case-law and the CJEU has clearly sought to ensure consistency by interpreting the Article 4 of the Charter in the same way. There is no reason why 'substantial grounds for believing' would not also apply under other Charter articles. However, it would be wrong to read into N.S. a requirement for there to be a widely documented systemic breakdown before substantial grounds can arise.

It is true that N.S. referred to the 'regular and unanimous reports of international non-governmental organisations bearing witness to the practical difficulties in the implementation of the Common European Asylum System in Greece, the correspondence sent by the United Nations High Commissioner for Refugees (UNHCR)'. ${ }^{60}$ But it did this in order to rebut the argument that Member States lacked the instruments to assess compliance by another Member State with the asylum directives. ${ }^{61}$ It was not, thereby, laying down a requirement, but simply confirming that the Charter required the Member States to take notice of objective evidence. It could usefully confirm that the same applies in the EAW context. It would not be appropriate, however, to simply assume that the same level of documentary evidence that existed in the Dublin context should be required in the EAW context. In the latter case, there is no 'Greece', the point of entry into the EU of nearly every asylum-seeker, on which charities could converge. Nor is there an equivalent of the UNHCR, a UN-funded body with a dedicated remit. Judgments of the ECtHR and CJEU against the country in question constitute equally if not more reliable evidence, which can be more effectively ac case, the Court accepted that fundamental rights maycessed and appraised by criminal courts in the short time-frame of an EAW case.

Finally, it should be noted that N.S. did not establish that there was any burden of proof on the asylum-seeker. The CJEU cannot be expected to address this point at length in the Radu reference, since no question to that effect has been asked. By precaution we would however state that the ECtHR in M.S. S. was adamant that it was up to the Belgian authorities, faced with the picture presented by the evidence in the public domain, 'not merely to assume that the applicant would be treated in

\footnotetext{
${ }^{59}$ N.S., at [94].

${ }^{60}$ N.S., at $[90]$.

${ }^{61}$ See N.S., at [91]
} 
conformity with [ECHR] standards ... but, on the contrary, to first verify how the Greek authorities applied their legislation on asylum in practice'. ${ }^{62}$ At no stage was a burden placed on the asylum-seeker. Rules of evidence which, in the more formalised context of judicial extradition proceedings, place an undue burden on the requested person, may therefore not be compliant with the Charter.

\section{Conclusion}

The purpose of this contribution was to underline the importance of the issue canvassed in the fourth question in the Radu reference. There is currently a disparate practice among the Member States with regard to the question whether they are required, by overriding fundamental rights obligations, to derogate from the rule of mutual recognition. The ECtHR case-law shows that both the prohibition on inhuman or degrading treatment, and other rights, can ultimately require a Contracting State of the ECHR to refrain from sending a person to another jurisdiction. The protection afforded by the Charter cannot be lower, and it is submitted that it is in fact higher: Member States are entitled to expect higher levels of compliance from their fellow Member States, since they have undertaken collectively to meet higher standards. An interpretation of the Charter which allows Member States to demand that standard of each other, by refusing extradition unless it is complied with, would drive the advance of fundamental rights protection within the EU.

Since this article was submitted to the editor, Advocate-General Sharpston has delivered her Opinion on the case. ${ }^{63}$ On the fourth issue at question, she concludes that, in the N.S. case, the court accepted that fundamental rights may affect the legislative obligation of a Member State to transfer a person to another State (points 76 and 77). She considers that the ECtHR's „flagrant denial of justice“ test is „,too nebulous" and ,unduly stringent", and that the appropriate criterion under the Charter should be that ,the deficiency or deficiencies in the trial proocess should be such as fundamentally to destroy its fairness" (points 82 and 83). On the burden and standard of proof, the Opinion states that a high evidential threshold would be difficult to meet for someone facing extradiction, possibly with very few ressources at their disposal; instead, the requested person must persuade the decision-maker that his objections to the transfer are substantially well-founded (points 84 and 85).

Fair Trials International welcomes the invitation to depart from the unachievable flagrancy test. We would argue that breaches of the Defence Rights Directive - for instance, a failure to provide independent interpretations - would certainly represent deficiencies liable to destroy the fairness of a trial. We would also agree that regard should be had to the practical situation of the requested person in setting the standard of proof. On all aspects, it is hoped that the Court will take the opportu-

\footnotetext{
${ }^{62}$ M.S. S., at [359].

${ }^{63}$ Opinion of the Advocate-General Sharpston of 18 October 2012 in Case C-399/11 Radu [2012] ECR I-0000.
} 
nity to deliver helpful precedent on this key component of the EU policy and judicial cooperation system.

\section{Postscript}

Fair Trials International would happily have considered making formall observations on this case before the CJEU had this been possible. However, the CJEU does not allow third party intervention in proceedings referred for a preliminary ruling. This is because intervention at the CJEU can only be made in support of an order sought by a party to a case, where the person can establish an interest in the outcome of the case. Referred proceedings are non-contentious, so intervention is impossible.

The preliminary ruling is a dialogue between the national court and the CJEU, and each has a clearly delineated role. The national court supplies the factual context and explains how its national law works. It identifies the issues of EU law which are relevant to its decision, and the CJEU's role is restricted to interpreting the relevant provisions of EU law and supplying a useful answer to the national court. The CJEU thus has to base its decision on the facts provided to it.

Because of this, it would not be possible for interveners to play one of the key roles they play in common law jurisdictions, and before the ECtHR - providing 'impact evidence ${ }^{64}$ - in the same way. However, it would be incorrect to say that the CJEU is insensitive to context. Indeed, the CJEU requests notes de recherche of its library and documentation service to better understand the context of its decisions; it welcomes the observations of Member States, who are entitled as of right to intervene, and can offer their views based on a legitimate interest in the development of the law which will bind them.

Nothing would prevent reasonable organisations who, like governments, are legitimately concerned with the orderly development of the case-law, from playing a similar role. The CJEU's decisions, in all areas, have consequences not just for the parties to the referred proceedings but for all the Member States. The assistance of specialist organisations could help it understand those effects. Indeed, it is arguable that some organisations with a cross-border remit would be better placed to contribute than governments, whose purview is purely national. The AdvocateGeneral currently plays a bridging role between civil society and the Court, but cannot be expected to put forward someone else's arguments at any length.

Reforms to the Rules of Procedure, effective from November 2012, entail no change in this regard (a modification of the Statute would be required for any relaxation of the rules). Human rights organisations therefore have two choices. The first is to find a way into the national proceedings. The CJEU will admit observations from third parties who are part of the national litigation, and at least one court ${ }^{65}$ has recently granted an organisation leave to intervene in national

\footnotetext{
${ }^{64}$ See Justice, To Assist the court: third party interventions, October 2009.
} 
proceedings with the sole purpose of enabling them to intervene before the CJEU. With that in mind, Fair Trials International has recently begun a project comparing third-party intervention rules in EU Member States, which we will in due course publish. The second is simply to make do and contribute as effectively as possible through informal channels, as we have sought to do in the present contribution. It is safe to rely on the conscientiousness of the CJEU's personnel, who will consult the available literature when considering a case. This second option should be seen as a viable alternative by organisations interested in human rights litigation before the CJEU.

${ }^{65}$ See $M R$ and Others (EEA extended family members) Bangladesh [2010] UKUT 449 (IAC). The Upper Tribunal allowed the AIRE Centre to intervene on the basis that it was 'likely to have a relevant contribution to make on the problems that cause us difficulty'. 